\title{
Use of WebQuests in Mathematics Instruction: Academic Achievement, Teacher and Student Opinions ${ }^{i}$
}

\author{
Arzu Aydoğan Yenmez ${ }^{1, *}$, İlknur Özpinar ${ }^{1}$, Semirhan Gökçe ${ }^{2}$ \\ ${ }^{1}$ Department of Mathematics and Science Education, Niğde Ömer Halisdemir University, Turkey \\ ${ }^{2}$ Department of Computer Education and Instructional Technology, Niğde Ömer Halisdemir University, Turkey
}

Copyright $\bigcirc 2017$ by authors, all rights reserved. Authors agree that this article remains permanently open access under the terms of the Creative Commons Attribution License 4.0 International License

\begin{abstract}
WebQuests are designed to ensure meaningful learning by combining technology with a constructivist approach in the classroom setting. This study aims to examine the effect of WebQuests used in instruction on students' academic achievements and the student and teacher opinions on WebQuests. The participants of this study using the quasi-experimental method were composed of 78 ninth-grade students and five mathematics teachers. Within this scope, WebQuests for the attainments in the domains of Data, Counting and Probability learning in the ninth-grade curriculum were developed by the researchers. The academic achievement test developed by the researchers was applied to the experimental and control groups as pretest, posttest and delayed posttest. In the implementation process, the experimental group was expected to solve the non-routine problems within WebQuests. The student and teacher opinions on the implementation were received at the end. The SPSS software package was utilized for quantitative data analysis and the qualitative data were subjected to a content analysis in the study. Consequently, it was discovered that the WebQuest teaching strategy had a positive impact on the student learning retention. Furthermore, the themes obtained through teacher and student opinions and recommendations of the study emphasize important issues for future studies.
\end{abstract}

Keywords WebQuest, Mathematics Instruction, Academic Achievement, Teacher Opinion, Student Opinion

\section{Introduction}

Significant developments in computer and communication technology in recent years have paved the way for the intensive use of internet in several domains like education. Using internet as an instrument of interactive and cooperative study and effective research in education helps students structure their own knowledge. Use of internet as an information resource in in-class and out-of-class activities increases learner participation in the learning process by leading to utilizing different learning methods, supports the teacher-student interaction and enable students to study in cooperation [1]. Today's classrooms have been transitioning from ones in which teachers and course books are accepted as authorities to ones in which internet information resources are used. Yet, students need the acquisition of reliable information on internet, evaluation of the information on internet and separation of the useful information [2]. Several approaches have been developed for the effective use of internet within instructional activities. One of those approaches is WebQuest which was introduced by Bernie Dodge of San Diego State University in 1995. Dodge (1997) defines WebQuest as an activity based on the research in which students work interactively and acquire the information they would use from the internet [3]. Halat (2007) defined WebQuest as a kind of computer-based learning and teaching model [4]. The model is also defined as a teaching strategy [5-7]. It can be also said that WebQuest is a new teaching strategy of the constructivist approach that uses computer environment.

WebQuests are designed to ensure meaningful learning by combining technology with a constructivist approach in the classroom setting. WebQuest is an approach that helps improve critical thinking skills that adapts information to new situations, enhances social skills and encourages learning retention [8]. Indeed, it is put forth by several research studies that WebQuest activities contribute to students' academic achievements [9-14] and attitudes [11,15-17] positively. WebQuest strategy ensures the efficient participation of learners in the learning process in this sense. This strategy allows students to use internet as a resource and access the materials related to the area they study in. The fact that there is too much information on the internet, that options acquired using search engines are sometimes not suitable for the instructional objectives and that the suitable ones are identified stops students from focusing on the topic, therefore causing waste of time [18]. 
Via the WebQuests, students concentrate their attention on the information itself rather than searching the information in irrelevant areas. Task assigned in a WebQuest is prepared to support students' levels of thinking, analyzing, synthesizing and evaluating [19]. There are two types of WebQuests defined as being short term and long term [10]. The aim with short-term WebQuests is to acquire and integrate information. Following a short-term WebQuest, the learner acquires the information significantly and adds meaning to that information. Preparation and implementation of a short-term WebQuest may take one to three class hours. Long-term WebQuests aim at acquiring information to increase and simplify it. The learner analyzes the information in-depth, adapts it to different situations and has a grasp of it after a long-term WebQuest. Long-term WebQuests are applied in classrooms either for a week or a month. WebQuests vary from ordinary web pages by their attributes of configuration, content and presentation. The parts which a WebQuest must involve can be listed as introduction, task, process, resource, evaluation, and conclusion $[3,20]$. As the introduction is prepared to motivate students, its most important feature is that a work or an activity is presented to the student as an interesting scenario, case or story. The task part includes the explanation on what students are supposed to do in the activity, and this part should be interesting, motivating, original and can be directed by the student. Resource part comprises of websites specified by the instructor to assist students when performing the task. The selected resources need to be of high quality and suitable for the development of the targeted age group [21]. The process part is composed of the process steps. It helps students review the process to be conducted for delivering the task. According to Chandler (2003), this part should be focused on the use of information rather than on the search of information and designed to have learners use their time efficiently [22]. The evaluation part involves how the acquired information is to be organized, how results are to be evaluated and what the evaluation criteria are. The conclusion part comprises of the summarized information on what students have learned. It also includes encouraging elements regarding that students should expand their experience towards other areas.

When considering that WebQuest is a new teaching strategy of the constructivist approach in computer environment, it can be said that it aims meaningful and permanent learning like the constructivist approach. From the perspective of mathematics particularly, mathematical concepts and skills need to be associated with the learning areas in the mathematics curriculum, other disciplines and daily life so that meaningful and permanent learning can be achieved [23]. It is argued that WebQuest can be used as an effective strategy in mathematics education because it allows students to learn by themselves and having fun and it is an interesting, fun, guiding model that activates the student [4]. Even though there are studies performed with preservice teachers on the applicability of the WebQuest teaching strategy, few studies have been focused on learners' academic achievements with the support of teacher and student opinions. Hence, this study aims to examine the effect of WebQuests used in instruction on students' academic achievements and the student and teacher opinions on WebQuests.

\section{Methods}

The study used quasi-experimental research design comparing pretest, posttest and delayed posttest scores of both experimental and control groups.

\subsection{Participants}

The subject of the study was from the two $9^{\text {th }}$ grade [15-16 ages] classrooms of a high school in Osmaniye province in Turkey and they were randomly assigned as experimental or control group. Each classroom contained 39 students, so a total of 78 high school students constituted the sample of the study.

The opinions of the mathematics teacher who applied the activities and of the four mathematics teachers at the same school who examined the WebQuests and observed the activities were consulted. There are seven mathematics teachers in total at the school. While two of them reported that they did not want to participate in the study, one of the teachers volunteered for the executive role and the remaining four teachers wanted to be a part of the study as observers.

\subsection{Data Collection Instruments}

The researchers planned to investigate the effect of using WebQuests about data, counting and probability learning area of $9^{\text {th }}$ grade mathematics course. For this purpose, it was planned that an achievement test would be developed. But before that, the test plan was created and the table of specification covering the learning outcomes of data, counting and probability has been prepared for providing evidence for content validity. Instead of using newly written items, the researchers analyzed the items about the same topic used in large scale examinations by Student Selection and Placement Center (ÖSYM) between 2006 and 2015. The test containing 30 items was administered to 235 students as the pilot study. The test results were analyzed with ITEMAN program. Test's Cronbach alpha reliability coefficient was found to be 0.782 . The mean item difficulty and discrimination index of the test were calculated to be 0.582 and 0.372 , respectively. The results of the item analysis showed that the discrimination index of the items 2, 4, 7, 12, 24 and 25 in the pilot study was below 0.20 . The researchers analyzed and discussed on these 6 items and reached a consensus of removing these items from the test. So, the final 
test form containing 24 items have been implemented as the pretest, posttest and delayed post test.

\subsubsection{WebQuests}

The researchers developed four WebQuests, two WebQuests for data analysis sub-learning area and two WebQuests for probability sub-learning area of $9^{\text {th }}$ grade national mathematics curriculum [23].

Short-term WebQuest activities were prepared. The activities were designed to take about 3 class hours (135 minutes). Each WebQuest involves at least six parts: introduction, task, process, resources, evaluation, and conclusion. When preparing the WebQuests which are based on the constructivist learning approach, emphasis was laid on the fact that the tasks given are related to daily life situations, applicable and are organized to have the attention and curiosity of the students. By this means, it was aimed that students are motivated towards the lesson and the activities are performed efficiently [24, 25]. WebQuests also included open-ended questions that are associated with the attainments in the learning activities and require high level of thinking [26]. It was aimed through how students review their prior knowledge and convey their own perspectives to the activity to allow for the increase in the product diversity in the classroom [24, 25]. Since the students can avoid wasting time on useless subjects by specifying the internet resources about the area of subject by the attainments [27], attention was paid to the presentation of appropriate and efficient resources in consideration of the attainments which were associated with the activities in WebQuests. Different types of evaluation were integrated into the activities in an effort.

The details of the WebQuests are given below:

Data Analysis WebQuest 1 (DAW1): Pickle is one of the most favorite appetizers in Turkish cuisine. In this WebQuest, students are asked to find the optimum month of the year to make pickle. The students have tasks such as looking for different types of pickles, investigating the ingredients of each pickle, finding the monthly prices of each vegetables and analyzing the data. At the end, students make inferences based on the analysis and the representation of the data.

Data Analysis WebQuest 2 (DAW2): When you want to buy a car, you buy either brand new or a used car. In this WebQuest, students are asked to find the optimum second hand car based on some constraints within the internet site dealing more than 250.000 cars. Students are expected to filter some properties of cars such as brand, model year, gear type and fuel type to estimate the popular brand.

Probability WebQuest 1 (PW1): In Turkish lottery, three types tickets (quarter, harf and whole) have been sold in 81 provinces. In this WebQuest, students were first expected to obtain data about the lottery tickets and then analyzed it to find the optimum type and province to buy lottery tickets. There is a list of tasks to complete: looking for the information about Turkish lottery system, finding the results of the latest lotteries containing ticket types and the dealer sold, analyzing the data and interpreting the results as a presentation.

Probability WebQuest 2 (PW2): In the road network of Turkey, many traffic accidents have been occurred. Among a list of reasons, dangerous behaviors of drivers especially who refuse to respect the legal rules and moral rights of others is the leading factor in a traffic accident. In this WebQuest, students are asked to analyze the annual reports of the traffic accidents and do some inferences based on some probability calculations. At the end, students are focused on finding the city in which the occurrence of traffic accident is most and least probable.

An exemplary WebQuest is given in Figure 1 with its screenshots. 


\section{LET๊S PICKLLE유}

1. Introduction

2. Task

3. Process

4. Resources

5. Evaluation

6. Conclusion

\section{INTRODUCTION}

It is believed that the Mesopotamian are the first civilization to pickle in the Ancient Period. It is mentioned that Aristoteles praised the healing effect of pickled cucumber in $850 \mathrm{BC}$ and it is known that the Roman emperors, primarily Julius Caesar, had their troops eat pickles because it enhances their physical and mental strengths. There is also a record on how Napoleon regarded pickle as a source of courage for his soldiers.

Pickle is one of the most valuable foods inherited from our forefathers. It has been an essential element of the Turkish cuisine for generations, held dear on the tables and brought about its own culture. It is possible to see salesmen selling pickle in markets and bazaars and on itinerant stands.

Showcase of the pickle stores today are arrange in a festival of colors, so much so it makes your mouth water.

\section{LET'S PICKRLE.00}

\section{Introduction}

2. Task

3. Process

4. Resources

5. Evaluation

6. Conclusion

\section{TASK}

You father finally retires after 40 years of the exhausting pace of Istanbul and decided to open a pickle store to make use of time as he does not want to sit around at home. He plans to produce and sell mixed pickles with a budget of 10,000 Turkish Liras. However, he asks you to make a detailed research because he has no knowledge of the business.

Your task is to specify the ingredients needed for mixed pickle at the most optimal cost, decide in which month of the year these ingredients should be bought and package and price the pickle for sale. And you know mathematics is your best friend for this.

Why don't you help your father using your knowledge of data processing and graphic demonstration?

Figure 1. (continued). Screenshots of the WebQuest activity "Let's Pickle" 


\section{LET'S PICKLLE.:}
1. Introduction
2. Task
3. Process
4. Resources
5. Evaluation
6. Conclusion

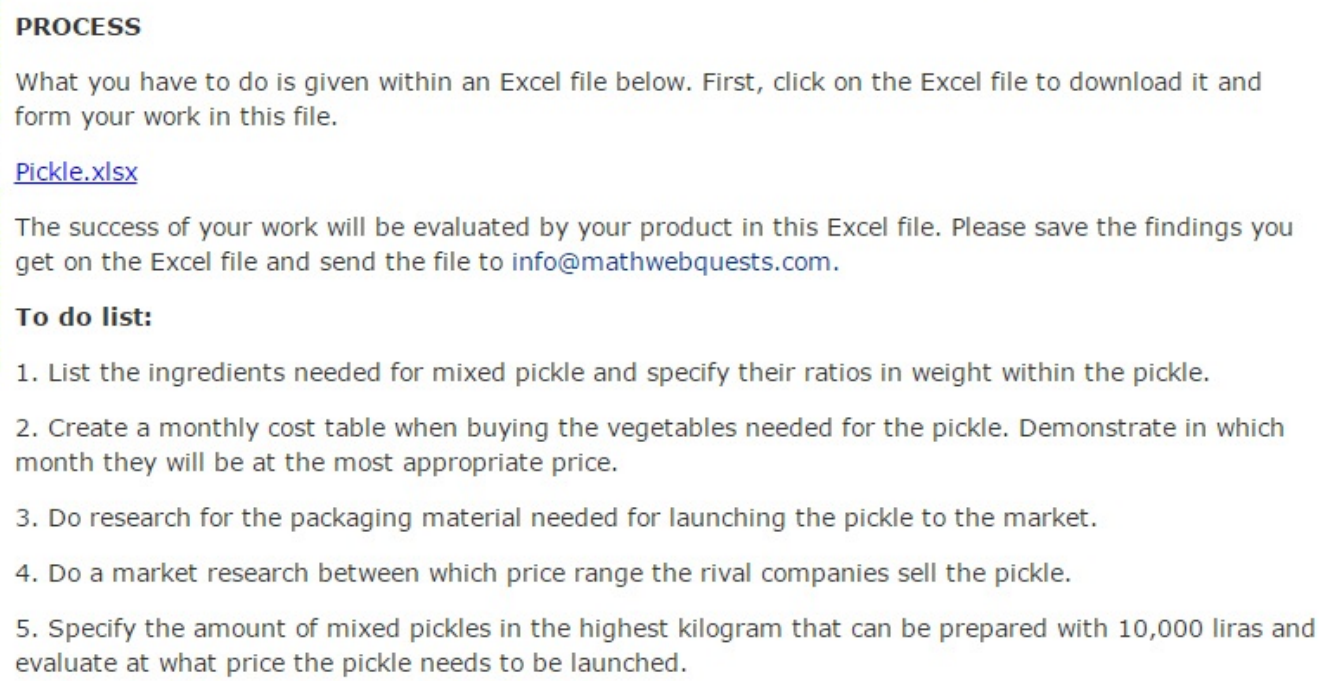

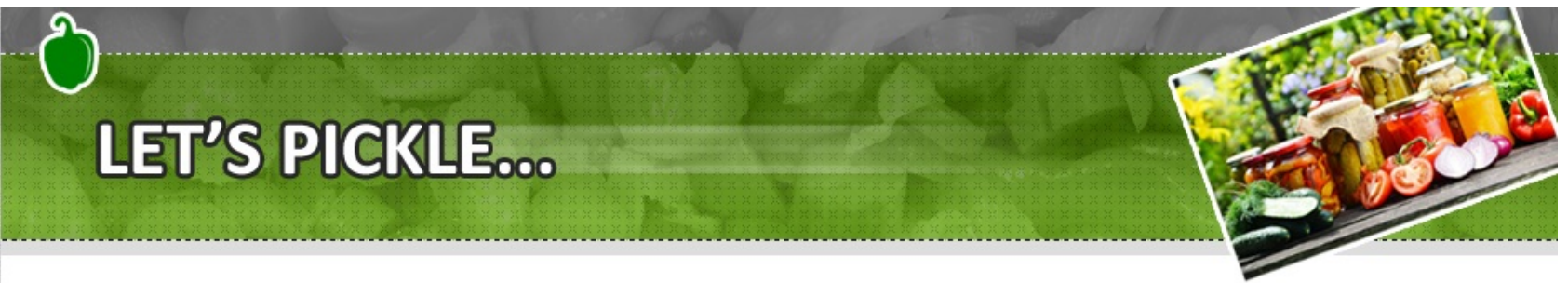

\section{Introduction}

2. Task

\section{Process}

4. Resources

5. Evaluation

6. Conclusion

\section{RESOURCES}

The following is the list of websites you can benefit from.

1. Istanbul Metropolitan Municipality Fruit-Vegetables Wholesale Market Website (http://halfiyatlari.ibb.gov.tr)

2. Istanbul Association of Fruit-Vegetables Brokers and Merchandisers Website (http://www.imeskom.com)

3. Hepsiburada.com Shopping Website (http://www.hepsiburada.com)

4. Sahibinden.com Shopping Website (http://www.sahibinden.com)

5. n11 Shopping Website (http://www.n11.com)

6. Yemek Tarifleri (Recipes) Website (http://www.yemektarifleri.com)

7. Nefis Yemek Tarifleri (Delicious Recipes) Website (http://www.nefisyemektarifleri.com)

8. Youtube Website (http://www.youtube.com)

9. UzmanTV Website (http://www.uzmantv.com)

Figure 1. (continued). Screenshots of the WebQuest activity "Let's Pickle" 


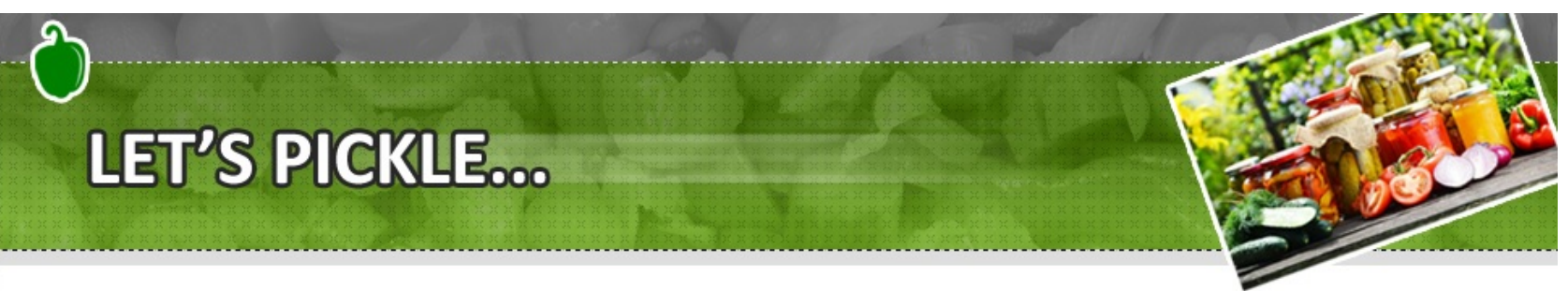

1. Introduction

2. Task

3. Process

4. Resources

5. Evaluation

6. Conclusion

\section{EVALUATION}

Your work will be evaluated and graded based on the criteria below. Please save the findings you get on the Excel file and send the file to info@mathwebquests.com.

\begin{tabular}{|c|c|c|c|c|}
\hline Criteria & $\begin{array}{l}\text { Detailed response } \\
\text { ( } 3 \text { points) }\end{array}$ & $\begin{array}{c}\text { Sufficient response } \\
\text { ( } 2 \text { points) }\end{array}$ & $\begin{array}{c}\text { Insufficient response } \\
\text { (1 point) }\end{array}$ & $\begin{array}{c}\text { No response } \\
(0 \text { point })\end{array}$ \\
\hline $\begin{array}{l}\text { Specifying the ingredients in } \\
\text { mixed pickle }\end{array}$ & $\begin{array}{l}\text { Specifying } 10 \text { and } \\
\text { more types of } \\
\text { ingredients in mixed } \\
\text { pickle by studying the } \\
\text { pickle recipes on } \\
\text { websites and listing the } \\
\text { ingredients of products } \\
\text { on the market }\end{array}$ & $\begin{array}{l}\text { Doing research on } \\
\text { websites to specify } 5 \text { to } \\
9 \text { types of ingredients } \\
\text { in mixed pickle }\end{array}$ & $\begin{array}{l}\text { Specifying } 1 \text { to } 4 \text { types } \\
\text { of ingredients in mixed } \\
\text { pickle on the websites or } \\
\text { from daily-life } \\
\text { knowledge }\end{array}$ & $\begin{array}{l}\text { Listing the ingredients in } \\
\text { mixed pickle without } \\
\text { referring to any } \\
\text { resource/Doing nothing } \\
\text { about the research on } \\
\text { the ingredients in mixed } \\
\text { pickle }\end{array}$ \\
\hline $\begin{array}{l}\text { Using the appropriate } \\
\text { numerical data in the } \\
\text { calculation of the most } \\
\text { economic time of the year to } \\
\text { pickle }\end{array}$ & $\begin{array}{l}\text { Calculating the cost of } \\
\text { mixed pickle with } \\
\text { appropriate numerical } \\
\text { data by considering the } \\
\text { availability rates of } \\
\text { ingredients needed for } \\
\text { mixed pickle and their } \\
\text { changes throughout the } \\
\text { year }\end{array}$ & $\begin{array}{l}\text { Calculating the cost of } \\
\text { mixed pickle without } \\
\text { appropriate numerical } \\
\text { data or by not } \\
\text { considering the } \\
\text { availability rates of } \\
\text { ingredients needed for } \\
\text { mixed pickle }\end{array}$ & $\begin{array}{l}\text { Calculating the cost of } \\
\text { mixed pickle without } \\
\text { appropriate numerical } \\
\text { data and by not } \\
\text { considering the } \\
\text { availability rates of } \\
\text { ingredients needed for } \\
\text { mixed pickle }\end{array}$ & $\begin{array}{l}\text { Anticipating the month in } \\
\text { which mixed pickle will } \\
\text { be produced with the } \\
\text { minimum cost without } \\
\text { depending on any } \\
\text { resource/Doing nothing } \\
\text { about the research on } \\
\text { specifying the most } \\
\text { appropriate period for } \\
\text { pickle }\end{array}$ \\
\hline \begin{tabular}{|l|} 
Doing research for the \\
packaging of the pickles and \\
pricing different types of \\
packaging
\end{tabular} & $\begin{array}{l}\text { Setting at least three } \\
\text { different types of } \\
\text { packaging and prices } \\
\text { for the produced pickle }\end{array}$ & $\begin{array}{l}\text { Setting two different } \\
\text { types of packaging and } \\
\text { prices for the produced } \\
\text { pickle }\end{array}$ & $\begin{array}{l}\text { Setting only one type of } \\
\text { packaging and prices for } \\
\text { the produced pickle }\end{array}$ & $\begin{array}{l}\text { No research on the } \\
\text { packaging of the } \\
\text { produced pickle }\end{array}$ \\
\hline $\begin{array}{l}\text { Doing market research for } \\
\text { rival pickle companies' price } \\
\text { policies }\end{array}$ & $\begin{array}{l}\text { Doing market research } \\
\text { on pickle prices on } \\
\text { websites and specifying } \\
\text { unit prices of at least } \\
\text { five rival companies }\end{array}$ & $\begin{array}{l}\text { Doing market research } \\
\text { on pickle prices on } \\
\text { websites and specifying } \\
\text { unit prices of three- } \\
\text { four rival companies }\end{array}$ & $\begin{array}{l}\text { Doing market research } \\
\text { on pickle prices on } \\
\text { websites and specifying } \\
\text { unit prices of one-two } \\
\text { rival companies }\end{array}$ & $\begin{array}{l}\text { No market research on } \\
\text { pickle prices on websites }\end{array}$ \\
\hline $\begin{array}{l}\text { Pricing the produced pickle } \\
\text { for sale and explaining its } \\
\text { rationale }\end{array}$ & $\begin{array}{l}\text { Setting the sales price } \\
\text { of the produced pickle } \\
\text { considering of all the } \\
\text { following: prices of the } \\
\text { ingredients, cost of } \\
\text { packaging, and the } \\
\text { rival company prices }\end{array}$ & $\begin{array}{l}\text { Setting the sales price } \\
\text { of the produced pickle } \\
\text { considering any two of } \\
\text { the following: prices of } \\
\text { the ingredients, cost of } \\
\text { packaging, and the } \\
\text { rival company prices }\end{array}$ & $\begin{array}{l}\text { Setting the sales price of } \\
\text { the produced pickle } \\
\text { considering any of the } \\
\text { following: prices of the } \\
\text { ingredients, cost of } \\
\text { packaging, and the rival } \\
\text { company prices }\end{array}$ & $\begin{array}{l}\text { Setting the sales price of } \\
\text { the produced pickle } \\
\text { regardless of any of the } \\
\text { following: prices of the } \\
\text { ingredients, cost of } \\
\text { packaging, and any of } \\
\text { the rival company } \\
\text { prices/Doing nothing } \\
\text { about the research on } \\
\text { the issue }\end{array}$ \\
\hline
\end{tabular}

Figure 1. (continued). Screenshots of the WebQuest activity "Let's Pickle" 


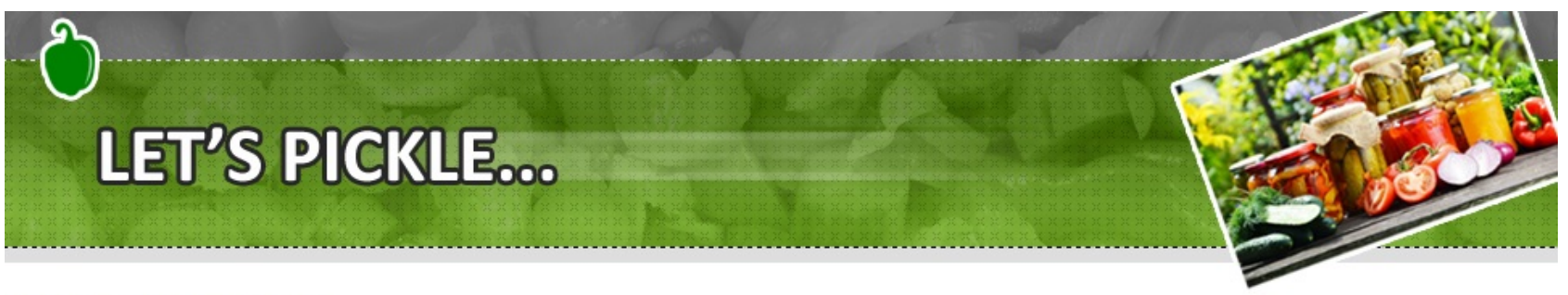

1. Introduction

2. Task

3. Process

4. Resources

5. Evaluation

6. Conclusion

\section{CONCLUSION}

Finally, click here to complete the survey in the pop-up. Remember to send the Excel file including your product and the answers to the following questions to info@mathwebquests.com.

1. Does your prediction for the solution before the activity coincide with the product result you achieved?

2. Do you think your product meets what you were asked?

3. Can your product be applied to different situations in mathematics?

By using the MS Excel electronic spreadsheet software properly and efficiently, you first tabulated the data you obtained on the internet and then demonstrated and interpreted them via different types of graphics.

The researchers developed such an activity by facing you with a non-routine mathematics problem situation within the scope of daily life so that you can improve your skills of using internet efficiently to access the resources you need (information, video, application, etc.). Searching for information on the internet to gather the useful pieces together and demonstrate them in tables and graphics and interpreting them is some of the important skills emphasized in the $9^{\text {th }}$ to $12^{\text {th }}$ Grade Mathematics Curriculum.

This activity mainly aims to improve your competence on interpreting the representations of data groups that reflect a real-life situation in appropriate types of graphics (scatter, box, line, etc.)

Figure 1. (continued). Screenshots of the WebQuest activity "Let's Pickle"

\subsubsection{Written Opinion Form and Semi-Structured Interviews}

The opinions of the experimental group students on the WebQuest activity were received through written opinion forms. The exemplary written opinion form questions are as follows: What do you think the WebQuest activities performed via the website have provided you with? What and how would you change in the activities if you were asked to improve such an activity to be performed via the website? In consideration of the academic achievement categories (poor, moderate, and good), two students from each category were chosen to perform the semi-structured interviews with six students in total. Semi-structured interviews were also performed with the mathematics teacher who applied the activities and of the four mathematics teachers at the same school who examined the WebQuests and observed the activities. The exemplary questions of the interviews are as follows: How do you think the WebQuest problem solutions affect students' learning? What kind of a part would you add if you would like to on the basis of the introduction, task, process, etc. parts of the WebQuests applied? Why? What can be the benefits and limitations of the WebQuest usage in mathematics instruction? What do you think of using WebQuest in your future instructions? The questions in the written opinion form was prepared by three field experts and they paid attention to the fact that the questions are easily understandable, open ended and do avoid from manipulation
[28:122]. The opinion of a Turkish education expert was received when preparing the interview forms and the pilot interview was performed with two ninth-grade students and two preservice teachers.

\subsection{Implementation Process}

First of all, mathematics achievement test was given to both experimental and control groups as a pretest. After implementing the WebQuest activities only to the experimental group as the treatment, mathematics achievement test was given to both groups as a posttest. Finally, three months after the posttest, mathematics achievement test was again implemented to both groups as a delayed posttest to identify the permanent effects of WebQuests on students' data, counting and probability achievements. The design of the study was given in Table 1 .

Table 1. The design of the study

\begin{tabular}{|c|c|c|c|c|}
\hline Group Type & Pretest & Treatment & Posttest & $\begin{array}{c}\text { Delayed } \\
\text { Posttest }\end{array}$ \\
\hline Experimental & $\mathrm{O}_{1}$ & $\mathrm{X}$ & $\mathrm{O}_{2}$ & $\mathrm{O}_{3}$ \\
\hline Control & $\mathrm{O}_{1}$ & & $\mathrm{O}_{2}$ & $\mathrm{O}_{3}$ \\
\hline
\end{tabular}

The same teacher performed the instruction of both experimental and control groups. Instructions based on the learning subareas of data and probability took 24 class hours 
(4 weeks). As a treatment, only the experimental group students solved the four WebQuests which took three class hours in elective courses as a group each week. The experimental group students completed a WebQuest that was appropriate for the attainments instructed each week in the computer laboratory. They accessed the WebQuests on http://www.MathWebQuests.com. During the class hours in which the WebQuests were solved, the executive teacher only acted as a guide in the group works. The other four teachers observed the activity. The WebQuest solutions were evaluated by five teachers. After the groups had delivered the solutions, they shared and discussed them under the leadership of the executive teacher.

\subsection{Data Analysis}

The SPSS software package was used in the study to analyze the quantitative data. Mean scores, standard deviations and t-test were utilized in the analysis of the quantitative data. The qualitative data were subjected to a content analysis and were mentioned as transcriptions regarding the coding along with the frequency and percentage values. Similar data among the answers given to the questions in the semi-structured interviews and the statements given in the written opinion forms were encoded for creating certain themes and parts that exhibit consistency and integrity between them were identified. The raw data obtained from the research were encoded by three experts individually to ensure the reliability of the process and the coding reliability was calculated using the fit index [29]. Since $70 \%$ and above is considered acceptable, it can be said that the fit index of $85.24 \%$ achieved the coding reliability on an acceptable level [30].

\section{Findings}

The pretest, posttest and delayed posttest results of the study are given below.

\subsection{Pretest Results}

Mathematics achievement test was implemented to both groups as a pretest to identify whether there was a significant mean difference between the groups. Independent samples t-test results of mathematics achievement test are given in Table 2.

Table 2 shows that there is no statistically significant mean difference between the pretest scores of experimental and control groups $\left(\mathrm{t}_{(76)}=0,359, \mathrm{p}>, 05\right)$.

\subsection{Posttest Results}

After the treatment was given only to the experimental group, mathematics achievement test was implemented again to both groups but now as a posttest to determine the efficiency of the treatment in a short time period. Actually, the mean scores of the experimental group is higher than the scores of control group. However, independent samples t-test results of posttest indicate that there is no statistically significant mean difference between the groups as shown in Table $3\left(\mathrm{t}_{(76)}=0,884, \mathrm{p}>, 05\right)$.

\subsection{Delayed Posttest Results}

Three months after the posttest, mathematics achievement test was implemented once more to determine the permanent effects of WebQuests on data analysis and probability. Table 4 showed that there was a statistically significant mean difference between the mathematics achievement delayed posttest scores of the groups in favor of the experimental group $\left(\mathrm{t}_{(76)}=2,322, \mathrm{p}<, 05\right)$.

When examining the solutions of the WebQuests and the different mathematical models achieved, it is seen that the student groups formed different mathematical models in their partially or completely correct solutions. Table 5 (Group A) and Table 6 (Group B) presents the different solutions proposed by the two groups for the WebQuest in Figure 1.

Table 2. Independent samples t-test results of pretest scores

\begin{tabular}{|c|c|c|c|c|c|c|}
\hline Group & N & $\bar{X}$ & SD & df & t & p \\
\hline Control & 39 & 39,0 & 13,9 & 76 & $-0,359$ & 0,720 \\
\hline Experimental & 39 & 37,9 & 12,5 & & & \\
\hline
\end{tabular}

Table 3. Independent samples t-test results of posttest scores

\begin{tabular}{|c|c|c|c|c|c|c|}
\hline Group & N & $\bar{X}$ & SD & df & t & p \\
\hline Control & 39 & 67,7 & 16,2 & 76 & 0,884 & 0,379 \\
\hline Experimental & 39 & 70,9 & 16,1 & & & \\
\hline
\end{tabular}

Table 4. Independent samples t-test results of delayed posttest scores

\begin{tabular}{|c|c|c|c|c|c|c|}
\hline Group & N & $\bar{X}$ & SD & df & t & p \\
\hline Control & 39 & 55,1 & 14,9 & 76 & 2,322 & 0,023 \\
\hline Experimental & 39 & 63,3 & 16,4 & & & \\
\hline
\end{tabular}


Table 5. Solution of group A for the WebQuest in Figure 1

\begin{tabular}{|c|l|c|c|c|c|c|c|c|c|c|c|c|c|}
\hline \multirow{2}{*}{$\begin{array}{c}\text { Item } \\
\text { Nr. }\end{array}$} & \multirow{2}{*}{ Ingredients } & \multicolumn{10}{|c|}{ Price } \\
\hline & & Jan & Feb & Mar & Apr & May & Jun & Jul & Aug & Sep & Oct & Nov & Dec \\
\hline $\mathbf{1}$ & Cabbage & 2.0 & 2.0 & 2.0 & 2.0 & 1.5 & 2.0 & 1.5 & 1.5 & 1.5 & 1.5 & 1.5 & 2.0 \\
\hline $\mathbf{2}$ & Cucumber & 7.0 & 7.0 & 5.0 & 5.0 & 3.5 & 0.8 & 0.8 & 0.8 & 2.5 & 3.0 & 3.0 & 3.5 \\
\hline $\mathbf{3}$ & Green Pepper & 9.0 & 8.0 & 7.5 & 6.0 & 3.5 & 4.0 & 3.0 & 4.0 & 3.0 & 4.5 & 5.0 & 6.0 \\
\hline $\mathbf{4}$ & Tomato & 6.0 & 4.5 & 4.5 & 5.0 & 4.0 & 3.5 & 2.0 & 1.5 & 3.5 & 4.5 & 4.5 & 5.0 \\
\hline $\mathbf{5}$ & Carrot & 0.5 & 0.5 & 0.5 & 0.5 & 0.5 & 0.5 & 0.6 & 0.6 & 0.6 & 0.5 & 0.5 & 0.5 \\
\hline $\mathbf{6}$ & & & & & & & & & & & & & \\
\hline $\mathbf{7}$ & & & & & & & & & & & & & \\
\hline $\mathbf{8}$ & & & & & & & & & & & & & \\
\hline $\mathbf{9}$ & & & & & & & & & & & & & \\
\hline $\mathbf{1 0}$ & & & & & & & & & & & & & \\
\hline \multicolumn{2}{|c|}{ Total cost (TL) } & $\mathbf{2 4 . 5}$ & $\mathbf{2 2 . 0}$ & $\mathbf{1 9 . 5}$ & $\mathbf{1 8 . 5}$ & $\mathbf{1 3 . 0}$ & $\mathbf{1 0 . 8}$ & $\mathbf{7 . 9}$ & $\mathbf{8 . 4}$ & $\mathbf{1 1 . 1}$ & $\mathbf{1 4 . 0}$ & $\mathbf{1 4 . 5}$ & $\mathbf{1 7 . 0}$ \\
\hline
\end{tabular}

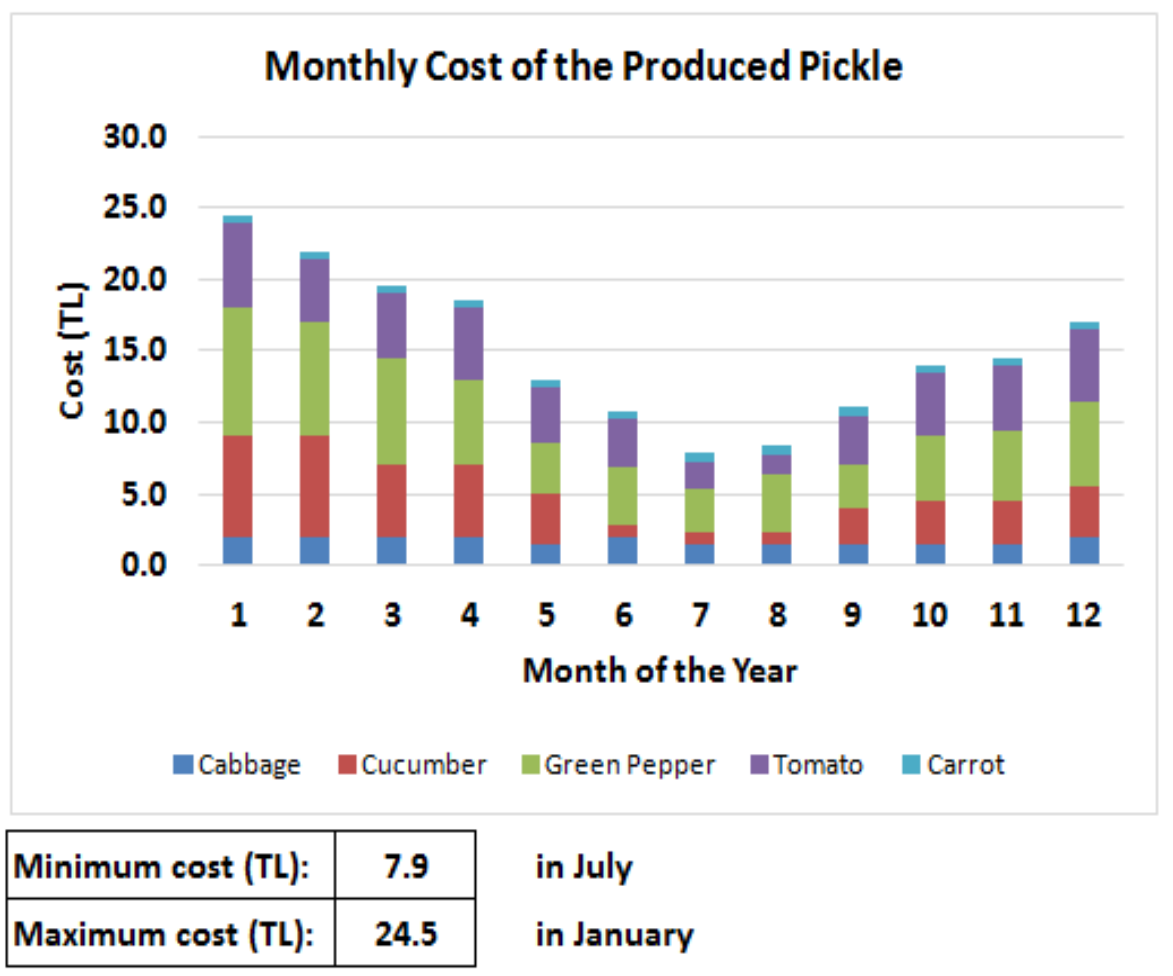

\section{Packing cost}

\begin{tabular}{|c|l|c|c|}
\hline ID & Packing material & Capacity (Liter) & Price (TL) \\
\hline 1 & Plastic can & 5 & 2.7 \\
\hline
\end{tabular}

\section{Marketing Research}

\begin{tabular}{|c|l|c|c|c|}
\hline ID & Name of the Rival Firm & Total Price (TL) & Weight (kg) & Unit price (TL/kg) \\
\hline 1 & Gökçe Turşu & 28 & 5 & 5.6 \\
\hline 2 & Cihan Turşu & 26 & 4 & 6.5 \\
\hline
\end{tabular}


Final Outcomes

\begin{tabular}{|l|l|}
\hline What is the expected unit price of your pickle? & $11.24 \mathrm{TL}$ \\
\hline Please state your criteria in determining the price? & $\begin{array}{l}\text { Price of the ingredients and } \\
\text { packaging cost }\end{array}$ \\
\hline
\end{tabular}

Table 6. Solution of group B for the WebQuest in Figure 1

\begin{tabular}{|c|l|c|c|c|c|c|c|c|c|c|c|c|c|}
\hline \multirow{2}{*}{$\begin{array}{c}\text { Item } \\
\text { Nr. }\end{array}$} & \multirow{2}{*}{ Ingredients } & \multicolumn{10}{|c|}{ Price } \\
\cline { 2 - 13 } & Jan & Feb & Mar & Apr & May & Jun & Jul & Aug & Sep & Oct & Nov & Dec \\
\hline $\mathbf{1}$ & Cabbage & 1.5 & 1.2 & 0.5 & 0.8 & 1.3 & 1.2 & 0.8 & 1.0 & 1.0 & 1.2 & 1.5 & 1.5 \\
\hline $\mathbf{2}$ & Parsley & 0.5 & 0.5 & 0.6 & 0.8 & 0.8 & 0.5 & 0.5 & 0.5 & 0.4 & 0.4 & 0.8 & 0.8 \\
\hline $\mathbf{3}$ & Garlic & 3.0 & 5.0 & 3.0 & 2.0 & 3.0 & 2.5 & 2.5 & 4.0 & 4.0 & 4.0 & 4.0 & 4.0 \\
\hline $\mathbf{4}$ & Carrot & 0.5 & 0.6 & 0.5 & 0.5 & 0.5 & 0.5 & 0.5 & 0.6 & 0.5 & 0.5 & 0.5 & 0.5 \\
\hline $\mathbf{5}$ & Red pepper & 6.0 & 5.0 & 5.0 & 6.0 & 5.0 & 3.0 & 4.0 & 4.0 & 4.0 & 4.0 & 5.0 & 6.0 \\
\hline $\mathbf{6}$ & Green pepper & 6.0 & 5.0 & 5.0 & 6.0 & 5.0 & 3.0 & 4.0 & 4.0 & 4.0 & 4.0 & 5.0 & 6.0 \\
\hline $\mathbf{7}$ & Gherkin & 5.0 & 5.0 & 6.0 & 3.0 & 3.5 & 3.0 & 4.0 & 3.0 & 2.5 & 4.0 & 5.0 & 6.0 \\
\hline $\mathbf{8}$ & White cucumber & 2.0 & 2.3 & 2.5 & 1.5 & 1.7 & 1.5 & 2.0 & 1.5 & 2.0 & 2.5 & 3.0 & 1.0 \\
\hline $\mathbf{9}$ & Pickle pepper & 1.5 & 1.5 & 1.5 & 1.0 & 1.0 & 0.7 & 1.0 & 3.0 & 3.0 & 1.0 & 1.0 & 1.5 \\
\hline $\mathbf{1 0}$ & Tomato & 3.5 & 2.5 & 2.0 & 2.0 & 1.5 & 1.0 & 1.0 & 1.0 & 2.0 & 2.5 & 2.7 & 3.0 \\
\hline & Total cost (TL) & $\mathbf{2 9 . 5}$ & $\mathbf{2 8 . 6}$ & $\mathbf{2 6 . 6}$ & $\mathbf{2 3 . 6}$ & $\mathbf{2 3 . 3}$ & $\mathbf{1 6 . 9}$ & $\mathbf{2 0 . 3}$ & $\mathbf{2 2 . 6}$ & $\mathbf{2 3 . 4}$ & $\mathbf{2 4 . 1}$ & $\mathbf{2 8 . 5}$ & $\mathbf{3 0 . 3}$ \\
\hline
\end{tabular}

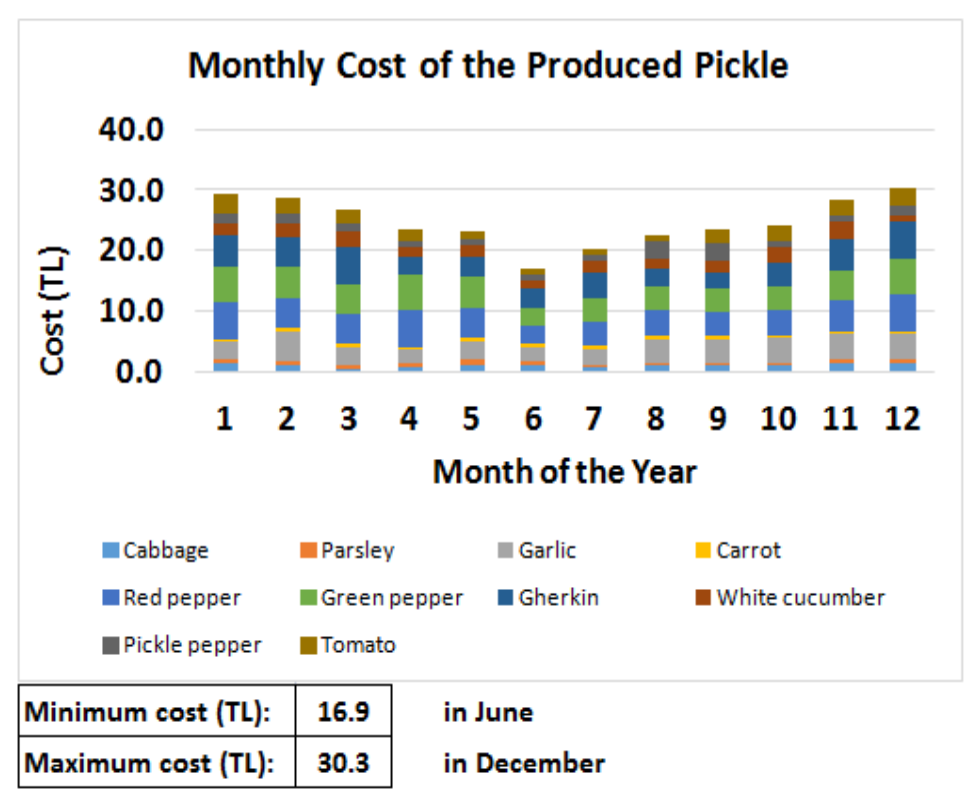

Packing cost

\begin{tabular}{|c|l|c|c|}
\hline ID & Packing material & Capacity (Liter) & Price (TL) \\
\hline $\mathbf{1}$ & Tin box & 18 & 8.4 \\
\hline $\mathbf{2}$ & Glass jar & 5 & 20.9 \\
\hline $\mathbf{3}$ & Plastic can & 5 & 2.7 \\
\hline
\end{tabular}


Marketing Research

\begin{tabular}{|c|l|c|c|c|}
\hline ID & Name of the Rival Firm & Total Price (TL) & Weight (kg) & Unit price (TL/kg) \\
\hline 1 & Soydan & 15 & 2 & 7.5 \\
\hline 2 & Gittigidiyor & 27 & 3 & 9.0 \\
\hline 3 & Ege Turşu & 10 & 1 & 10.0 \\
\hline 4 & Çubuk Turşu & 9 & 1 & 9.0 \\
\hline 5 & n11.com & 15 & 2 & 7.5 \\
\hline
\end{tabular}

Final Outcomes

\begin{tabular}{|l|l|}
\hline What is the expected unit price of your pickle? & $12 \mathrm{TL}$ \\
\hline Please state your criteria in determining the price? & \\
\hline
\end{tabular}

Exemplary evaluations made by an observer teacher for the solutions presented in the Table 5 (Group A) and Table 6 (Group B) in consideration of the criteria in the Evaluation part of the WebQuest are as follows:

Table 7. Evaluation for Group A by an observer teacher

\begin{tabular}{|c|c|c|c|c|}
\hline Criteria & $\begin{array}{l}\text { Detailed response } \\
\text { (3 points) }\end{array}$ & $\begin{array}{l}\text { Sufficient response } \\
\text { ( } 2 \text { points })\end{array}$ & $\begin{array}{l}\text { Insufficient response } \\
\text { (1 point })\end{array}$ & $\begin{array}{l}\text { No response } \\
(0 \text { point })\end{array}$ \\
\hline $\begin{array}{l}\text { Specifying the products } \\
\text { that should be in mixed } \\
\text { pickle }\end{array}$ & & $\begin{array}{c}\text { X } \\
\text { Only } 5 \text { types of } \\
\text { ingredients in mixed } \\
\text { pickle were listed. }\end{array}$ & & \\
\hline $\begin{array}{l}\text { Using the appropriate } \\
\text { numerical data in the } \\
\text { calculation of the most } \\
\text { economic time of the year } \\
\text { to pickle }\end{array}$ & & & $\begin{array}{c}\text { X } \\
\text { Cost of mixed pickle was } \\
\text { calculated regardless of } \\
\text { the availability rates of the } \\
\text { ingredients needed for } \\
\text { mixed pickle and without } \\
\text { using the appropriate } \\
\text { numerical data. }\end{array}$ & \\
\hline $\begin{array}{c}\text { Doing research for the } \\
\text { packaging of the pickles } \\
\text { and pricing different types } \\
\text { of packaging }\end{array}$ & & & $\begin{array}{c}\text { X } \\
\text { Only } 1 \text { type of packaging } \\
\text { and price was set for the } \\
\text { pickle packaging. }\end{array}$ & \\
\hline $\begin{array}{l}\text { Doing market research for } \\
\text { rival pickle companies' } \\
\text { price policies }\end{array}$ & & & $\begin{array}{c}\text { X } \\
\text { Market research was done } \\
\text { for the pickle prices on the } \\
\text { websites and unit prices of } \\
2 \text { rival companies were } \\
\text { determined }\end{array}$ & \\
\hline $\begin{array}{l}\text { Pricing the produced } \\
\text { pickle for sale and } \\
\text { explaining its rationale }\end{array}$ & & $\begin{array}{c}\mathrm{X} \\
\text { Sales price of the } \\
\text { produced pickle was set } \\
\text { considering any two of the } \\
\text { following: the prices of } \\
\text { the ingredients, cost of } \\
\text { packaging, and the rival } \\
\text { company prices. }\end{array}$ & & \\
\hline
\end{tabular}


Table 8. Evaluation for Group B by an observer teacher

\begin{tabular}{|c|c|c|c|c|}
\hline Criteria & $\begin{array}{l}\text { Detailed response } \\
\text { (3 points) }\end{array}$ & $\begin{array}{l}\text { Sufficient response } \\
\text { (2 } 2 \text { points })\end{array}$ & $\begin{array}{l}\text { Insufficient response } \\
\text { (1 point) }\end{array}$ & $\begin{array}{l}\text { No response } \\
(0 \text { point })\end{array}$ \\
\hline $\begin{array}{l}\text { Specifying the products } \\
\text { that should be in mixed } \\
\text { pickle }\end{array}$ & $\begin{array}{c}\mathrm{X} \\
10 \text { types of ingredients in } \\
\text { mixed pickle were listed. }\end{array}$ & & & \\
\hline $\begin{array}{l}\text { Using the appropriate } \\
\text { numerical data in the } \\
\text { calculation of the most } \\
\text { economic time of the year } \\
\text { to pickle }\end{array}$ & & $\begin{array}{c}\mathrm{X} \\
\text { The availability rates of } \\
\text { the ingredients needed for } \\
\text { mixed pickle were not } \\
\text { considered, but cost of } \\
\text { mixed pickle was } \\
\text { calculated using the } \\
\text { appropriate numerical } \\
\text { data. }\end{array}$ & & \\
\hline $\begin{array}{c}\text { Doing research for the } \\
\text { packaging of the pickles } \\
\text { and pricing different types } \\
\text { of packaging }\end{array}$ & $\begin{array}{c}\mathrm{X} \\
3 \text { types of packaging and } \\
\text { prices were set for the } \\
\text { pickle packaging. }\end{array}$ & & & \\
\hline $\begin{array}{l}\text { Doing market research for } \\
\text { rival pickle companies' } \\
\text { price policies }\end{array}$ & $\begin{array}{c}\text { X } \\
\text { Market research was done } \\
\text { for the pickle prices on the } \\
\text { websites and unit prices of } \\
5 \text { rival companies were } \\
\text { determined }\end{array}$ & & & \\
\hline $\begin{array}{l}\text { Pricing the produced } \\
\text { pickle for sale and } \\
\text { explaining its rationale }\end{array}$ & & & & $\begin{array}{c}\text { X } \\
\text { Price of the produced } \\
\text { pickle was set regardless } \\
\text { of any of the following: } \\
\text { the prices of the } \\
\text { ingredients, cost of } \\
\text { packaging, and the rival } \\
\text { company prices. The price } \\
\text { given is uncertain. }\end{array}$ \\
\hline
\end{tabular}

After the teachers had examined the solution process and all the solutions provided by the groups for each WebQuest, the following themes were identified out of student opinions on their learning and the benefits of using WebQuests in mathematics instruction (executive teacher was encoded as ET while other teachers were encoded as T1, T2, T3, and T4): permanent learning (ET, T1, T2, T3, and T4), appeal (ET, T1, $\mathrm{T} 2, \mathrm{~T} 3$, and $\mathrm{T} 4$ ), active participation (ET, T1, T2, T3, and T4), rehearsal (even if students are not at school) (ET, T1 and $\mathrm{T} 4)$, and association with daily life (ET, T1, T2, T3, and T4). In addition, the teachers stated that students can improve their skills of critical thinking (ET, T1, T3, and T4), creative thinking (ET, T1, T2, and T3) and establishing relationships (ET, T1 and T3). The following are the teacher opinions that support the themes.

"[T] he students constantly and actively studied during the solution process, and I understood from the questions I asked that they developed their solutions consciously of what they did. This is very important because they will not forget as they learned this way; they will always remember the concepts they used." (ET)

"[S]ince these are events in daily life, it attracted students' attention so much and this made them not stop working on the question." (T2)

"[O]ur four students who did not come to the school heard about the activities from their friends and they solved them at their homes at night, too. I think this is very important because students become bored of doing homework, but rehearsal is a must for learning. Actually, they get the chance to rehearse enjoyably at home or in other places through these activities."(T4)

"[...] I think these activities enabled students to do research. Because the subjects are intertwined with daily life, and they are curious about whether other subjects have these relationships ...they discuss such creative ideas and think from such different perspectives in the solutions. I think how students study through such activities should enhance critical thinking and skills of establishing relationship." (T1)

"[S]tudents brought us such creative solutions that I think their critical thinking will definitely improve." (T3)

As for teachers' opinions on whether they would use the WebQuest strategy in their future instructions, they stated that WebQuests on the internet are limited and inadequate, or the resources are insufficient, and reported that they would carry out the activities if they were prepared by experts (ET, $\mathrm{T} 1, \mathrm{~T} 2, \mathrm{~T} 3$, and T4). The teachers also mentioned about the difficulty in preparing the activities (ET, T1, T2, T3, and T4), waste of time (ET, T1 and T4), and the difficulty in specifying reliable internet resources ( $\mathrm{T} 1$ and $\mathrm{T} 4$ ).

"[I]f there were readily available activities like those, why not? I would like to use them very much. It drew my interest and I did research on the internet, found resources in English 
but I could not understand. My English is not that well actually. The resources I found in Turkish were not about mathematics, and two of them about mathematics were not suitable for our students (15-18 years old)." (ET)

"[W]e can't prepare it even if want to because it takes professionality to prepare these activities. It is hard and we don't know how to use computer" (T3)

"[I] am qualified in computer so I can build a scenario. But it is a time-taking task, no one has that much time." (T4)

"[I] can't prepare it because I can't use computer. Let's assume that I get help; then it is even great trouble to identify internet resources suitable for the scenario. If they are not reliable, children may do something wrong." (T1)

When examining teachers' opinions on the parts of WebQuests, they stated that the parts are appropriate and efficient (ET, T1, T2, T3, and T4) but they could study the learning objectives aimed with the WebQuest and provide solution before the implementation if there would be an informative page for them (ET, T1, and T4). Furthermore, the teachers suggested how they could direct the discussion by comparing all the solutions in the presentation part if students transferred their solutions to that page (ET and T4). This suggestion is presented below with a representative opinion:

"[I]t would be very good if there was a teacher page here. It might write what attainments, objectives this activity includes ...For instance, students would upload solutions as they completed them and all groups would see their solutions altogether. So, teachers would also see all the solutions together and discuss them in the presentations better. Teachers could share their solutions in the end and students would say 'that's what I thought." (T4)

The following themes were obtained out of the opinions stated by the teachers on the use of WebQuest strategy in mathematics instruction: teacher and student level of computer usage (ET, T1, T2, T3, and T4) and equipment, technical and network infrastructure of schools (ET, T1, T2, $\mathrm{T} 3$, and T4). The teacher opinions that support these themes is as follows:

"[H]ere, groups ask lots of things on the computer for the solutions. Let's say if I did not have the ability to use computer or students could not have used computer even on this level, the activity would have been very hard. We would have been talking about how we could use computer rather than the solutions. That's why both teachers and students should be using computer well." (ET)

"[S]chools need to have computer laboratories, internet networks and computers with necessary hardware. Otherwise, it would be very difficult. Even the slow internet connection is a major problem." (T1)

As for the student opinions on what they attained with the activity, $72 \%$ of them stated that they learned by having fun because they associated the activity with daily life. They also mentioned that this environment supported their cooperative learning. They highlighted the group works and reported that the group work was efficient because they learned something from each other (51\%). They argued how all group members had different perspectives strengthen the solution (80\%). They also emphasized that their motivation increased as they supported each other (85\%). Whereas the percentages above reflect all experimental group students, the following representative opinions were cited from the semi-structured interviews performed with six students (the students were encoded as Student 1 to Student 6).

" $[\mathrm{T}]$ he questions were so much fun, we lost the track of time. I think what attracted our interest was that it was about the life itself." (Student 2)

"[I] felt I learned by having fun in mathematics for the first time." (Student 1)

$[T]$ he group works were awesome. Everyone had an idea. I could not think of that much think by myself; I learned a lot from my friends ...I might have become frustrated and would not have wanted to go on when I could not think of anything if I had been alone. But we encouraged each other in the group; that's what made us produce lots of solutions." (Student 5)

The students reported that limited links in the part in which they evaluated the construct of the WebQuests were productive because they facilitated their concentration $(46 \%)$, the directives in the process part accelerated their decision mechanisms (59\%), and the questions in the conclusion part enabled them to review what they did and found (77\%). They suggested as an alteration that a page could be added to remind them of their preliminary knowledge $(28 \%)$. The following student opinions are on this subject:

"[I]f they had not given us those websites, we would have lost on the internet when searching for what was asked ...how they gave us what to do in the problem made us make quick decisions and concentrate." (Student 3 )

"[T]he questions asked in the end made us think over the solution. We sometimes noticed our insufficiency and got back to the question." (Student 6)

"[F]or example, it would have been better if there had been a some kind of reminder part which would include mathematical information we would use in the question." (Student 5)

\section{Discussion and Conclusions}

In this study which aimed to examine the effects of WebQuests used in mathematics instruction on students' academic achievements and the student and teacher opinions on WebQuests, it was discovered in the light of the results achieved on the pretest-posttest mean scores of the academic achievement test that there was no significant difference between academic achievements of the experimental and control groups. Yet, when considering the delayed posttest scores of the groups, there was a significant difference by academic achievement in favor of the experimental group. Consequently, it was discovered that the WebQuest strategy had a positive impact on retention. It is seen that previous 
studies focused rather on academic achievement regardless of retention $[7,9,11,31]$. On the other hand, not many studies have been performed on the WebQuest's effect on retention of information in students. Smith and Robinson (2003) stated that instruction with WebQuests increase the retention time of important concepts compared to the traditional instruction [32]. Halat (2007) stated that the WebQuest strategy allowed learners to regard their learning as being permanent and effective [4].

As for the teacher opinions, the themes of permanent learning, appeal, active participation, rehearsal (even if students are not at school), and association with daily life were obtained on student learning and the use in mathematics instruction. Teachers' opinion that students can learn permanently through the WebQuest strategy coincide with the result achieved by Zencirci and Asker (2009) that WebQuests can offer permanent learning by making students advance step by step [33]. Similarly, how instruction with WebQuests supports permanent learning has been also mentioned in other studies $[4,32]$. When considering the learning environment, it is emphasized in several studies that the activities are fun and interesting and do achieve active participation as they are associated with daily life [33-35]. In the study conduct by Manning and Carpenter (2008), the preservice teachers stated that the courses using WebQuests are more enjoyable and interactive than traditional courses [35]. In parallel, some studies emphasize that they would draw students' interests and motivate them even further $[33,34]$. Teachers' opinion that students have the chance to rehearse the subject anywhere even if they are not at school can be interpreted as the fact that WebQuests allow for rehearsal of the subjects regardless of time and space due to their accessibility. In addition, the teachers stated that students can improve their skills of critical thinking, creative thinking and establishing relationships. Teachers' opinion that WebQuests may enhance critical thinking contradicts with the result of the study performed by Yücel (2011) [36]. This study concluded that mathematics instruction supported by WebQuest had no impact on sixth-grade students' critical thinking skills [36]. However, it was observed that the structure of the WebQuest problem-solving process turned into a new structure that is constructivist problem solving which shows that theoretical structure of critical thinking is a broad process including critical thinking, usage of information, establishing relationships and structuring. It can be inferred from such opinions of the teachers that there is a high expectation that critical thinking is activated in constructivist problem solving. These opinions are also in parallel with the opinions of the participants in another study that WebQuests can improve learners' higher-order thinking skills such as critical thinking, creative thinking and learning how to learn [33].

As for teachers' opinions on whether they would use the WebQuest strategy in their future instructions, they stated that WebQuests on the internet are limited and inadequate, or the resources are insufficient, and reported that they would carry out the activities if they were prepared by experts. They also reported that the activities were difficult to prepare, took time and it was hard to identify reliable internet resources. Similarly, the preservice teachers in the study by Halat (2007) stated that it was difficult and time-consuming to prepare the WebQuest and to perform it as there were no sufficient internet resources in Turkish [4]. Furthermore, it was reported in the study performed by Halat and Jakubowski (2001) with 19 preservice teachers who were attending the secondary and elementary education teaching department at a state university in Florida that there are limitations to WebQuests such as no internet connection, how teacher spends too much time to prepare the WebQuest and insufficiency of reliable internet resources [37]. In addition, the following themes were obtained out of the opinions stated by the teachers on the use of WebQuest strategy in mathematics instruction: teacher and student level of computer usage and equipment, technical and network infrastructure of schools. In parallel with the results of this study, Manning and Carpenter (2008) emphasize that using WebQuest would cause restrictions for those who are not competent enough on computer [35]. Zencirci and Asker (2009) also argued how not every school in Turkey has the same equipment and technical and network infrastructure hinders the usage of WebQuests [33]. It is seen that the results of this study are similar with the findings in the literature. It can be consequently said in the light of the studies in the literature and the teacher opinions that these factors are major obstacles before the implementation of the WebQuest strategy in classrooms by teachers.

When examining teachers' opinions on the parts of WebQuests, they stated that the parts are appropriate and efficient. However, they could study the learning objectives aimed with the WebQuest and provide solution before the implementation if there would be an informative page for them. Furthermore, the teachers suggested how they could direct the discussion by comparing all the solutions in the presentation part if students transferred their solutions to that page. This suggestion is similarly mentioned in the literature as the 'teacher page'. It was stated in the study by Jones (2004) that a teacher page should be allocated to teachers in WebQuests and that this page can include learning objectives aimed with WebQuest and recommendations about the proper usage of WebQuest [38]. These recommendations of the teachers can be understood as a positive development in the sense that they interpret the construct of the WebQuest in a good way.

The students stated that the tasks associated with daily life enabled them to learn by having fun. They also mentioned that this environment supported their cooperative learning. They highlighted the group work and reported that the group work was efficient because they learned something from each other. They argued how all group members had different perspectives strengthen the solution. They also emphasized that their motivation increased as they supported each other. It is seen in the studies in the literature that 
association of the tasks in WebQuests with daily life reinforces the applicability of the activities in teaching [20, 39-41]. The student opinions in this study that they learned by having fun with the tasks associated with daily life coincide with the result achieved by Gaskill, McNulty and Brooks (2006) that WebQuests make the learning-teaching process more enjoyable both for students and teachers [42]. The student opinions that activities paved the way for a cooperative environment and on the effectiveness of group work are in parallel with the results of different studies $[6,11,43,44]$. It has been discovered that WebQuest help students on different instructional levels with learning and use of WebQuests motivate students for learning and help them learn $[6,43,44]$. It is also stated that group work in WebQuest activities would improve the learning experience, enhance the learning efficiency and may provide students with multiple perspectives [11]. It can be said in the light of these opinions that WebQuests are activities that support learning.

The students reported that limited links in the part in which they evaluated the construct of the WebQuests were productive because they facilitated their concentration, the directives in the process part accelerated their decision mechanism, and the questions in the conclusion part enabled them to review what they did and found. They suggested that a page could be added to remind of preliminary information. The evaluations made by the students for the parts of WebQuest coincide with the attributes mentioned in the literature. For instance, according to Chandler (2003), the process part should be focused rather on using the information than searching for it and designed to have learners use time efficiently [22] whereas Sandars (2005) argue that a probing question which to stimulate their further thoughts, should be included about the student attainments in the conclusion part [45]. When considering the student opinions in the study, it can be said that the students made sense of the construct of the WebQuests and provided affirmative evaluations. It is, however, thought that the suggestion by the students that a page can be added to remind them of their preliminary knowledge may bring about certain difficulties. Because students may think that the mathematical concepts given on such a page must be used and this restriction may limit students' solution approaches.

Consequently, it was discovered in this study that the WebQuest teaching strategy had a positive impact on the student learning retention. Furthermore, teachers' opinions on WebQuest strategy's effect on student learning, benefits and limitations of its use in mathematics instruction, students' higher-order thinking skills, whether they would use this strategy in their future instructions, and the construct of WebQuest and students' opinions on what they attained with the activity and the construct of WebQuest emphasize important issues for the future activities. It is important for teachers to improve their computer skills so that they can prepare the WebQuest activities and perform those activities in mathematics instruction to apply the WebQuest strategy efficiently. In this sense, possible inadequacy of internet connection and the fact that teachers cannot find the time and reliable websites to develop a WebQuest activity should be considered among the limitations. It is accordingly critical that teachers receive interactive trainings in which they prepare and perform WebQuest activities and evaluate the instruction and efficiency in in-service and preservice education.

\section{REFERENCES}

[1] Ritter, M. \& Lemke, K. "Addressing the 'Seven Principles for Good Practice in Undergraduate Education' with Internet-enhanced Education". Journal of Geography in Higher Education, 24pp, 2000.

[2] Clark, D. B. Evaluating media- enhancement and source authority on the internet: the knowledge integration environment. International Journal of Science Education, 22 (8), 859-871, 2000.

[3] Dodge, B. Some thoughts about WebQuests [online], 1997. (05 April 2017);

http://WebQuest.sdsu.edu/about_WebQuests.html.

[4] Halat, E. Matematik öğretiminde WebQuestin kullanımına ilişkin öğretmen adaylarının görüşleri [Preservice teacher opinions on using WebQuest in mathematics instruction]. Illkögretim Online, 6 (2), 264-283, 2007.

[5] Crawford, C. M. \& Brown, E. Focusing Upon Higher Order Thinking Skillls: WebQuests and The Learner-Centered Mathematical Learning Environment, 2002. ERIC. Access date: 07.03.2017.

[6] March, T. Why WebQuests? An Introduction, 1998. http://tommarch.com/writings/intro_wq.php. Access date: 20.12.2016.

[7] Segers, E., \& Verhoeven, L. Learning in a sheltered Internet environment: the use of WebQuests. Learning and Instruction, 19(5), 423-432, 2009.

[8] Zheng, R., Stucky, B., McAlck, M., Menchana, M., and Stoddart, S. WebQuest learning as perceived by higher-education learners. TechTrends, 49 (4), 41-49,2005.

[9] Memişoğlu, B. Matematik öğretiminde bilişim teknolojilerinin kullanımı [Use of information technologies in mathematics instruction]. Postgraduate Thesis, Balıkesir University, Institute of Science, Balıkesir, 2005.

[10] Çığrık, E. İlköğretim 6.sınıf fen öğretiminde WebQuest tekniğinin öğrenci başarısı ve tutumuna etkisinin incelenmesi [An examination of the effects of WebQuest method on student achievement and attitude in elementary school sixth-grade science instruction]. Postgraduate Thesis, Uluda $\breve{g}$ University, Institute of Social Sciences, Bursa, 2009.

[11] Akçay, A. WebQuest (web macerası) öğretim yönteminin Türkçe dersindeki akademik başarı ve tutuma etkisi [How WebQuest teaching method affects academic achievement and attitude in the Turkish language lesson]. Postgraduate Thesis, Atatürk University, Institute of Social Sciences, Erzurum, 2009. 
[12] Börekci, C. Bilișim teknolojileri dersi için tasarlanan bir ağ araştırması (WebQuest) etkinliğinin öğrenci başarısı üzerine etkisi [Effects of a WebQuest activitiy designed for the information technologies class on the student achievement]. Postgraduate Thesis, Balıkesir University, Institute of Science, Balıkesir, 2010.

[13] Şahin, N. 6. sınıf bilişim teknolojileri dersinde ağ araştırması (WebQuest) aracı kullanarak oluşturulan eğitim ortamının akademik başarı ve derse karşı olan tutuma etkisi [How the educational environment created using the WebQuest instrument insixth-grade information technologies lesson on academic achievement and the lesson]. Postgraduate Thesis, Gazi University, Institute of Educational Sciences, Ankara, 2010 .

[14] Gökalp, M. S. The effect of WebQuest based instruction on ninth grade students' achievement in and attitude towards force and motion. PhD Thesis, The Middle East Technical University, Ankara, 2011.

[15] Kılıç, R. WebQuest destekli işbirlikli öğrenme yönteminin matematik dersindeki tutum ve başarıya etkisi [Effects of WebQuest-aided cooperative learning method on the attitude and achievement in mathematics lesson]. Postgraduate Thesis, Eskişehir Osmangazi University, Institute of Social Sciences, Eskişehir, 2007.

[16] Özerbaş, M. A. WebQuest öğrenme ortamının öğrencilerin akademik başarı ve tutumlarına etkisi [Effects of WebQuest learning environment on students' academic achievement and attitudes]. Ahi Evran Üniversitesi Kırșehir Eğitim Fakültesi Dergisi (KEFAD), 13 (2), 299-315, 2012.

[17] Üzel, D. WebQuest based learning: the attitudes of primary students towards mathematics. The New Educational Review, 27 (1), 209-220, 2012.

[18] Faichney, G. WebQuest: A strategy for teaching sose online, ETHOS, 6 (10), 145-168, 2002.

[19] Kurtuluş, A., Tepe, A., Yılmaz, S., Karakoç, Ö. \& Okur, G. İlköğretim Matematik Sinıflarında WebQuest Uygulamaları [WebQuest Applications in Elementary School Mathematics Classes]. 6th International Educational Technology Conference. Eastern Mediterranean University, Famagusta, KKTC, p.1194- 1201, 2006.

[20] Kundu, R. \& Brain, C. WebQuests: Utilizing technology in a constructivist manner to facilitate meaningful preservice learning. Art Education, 59 (2), 6-11, 2006.

[21] Akçay, A., \& Şahin, A. (Bir öğretim yöntemi olarak web maceras1 [WebQuest as a teaching method]. Bilişim Teknolojisi Dergisi, 6(1), 17-22, 2013

[22] Chandler, H. Concept mapping and WebQuests in social studies. Media and Methods, Volume: 39, Issue: 3, p. 38-39, 2003.

[23] Ministry of National Education. Ortaöğretim matematik dersi $(9,10,11$ ve 12 . Sinıflar) dersi öğretim programı ve kılavuzu / Secondary education $\left(9^{\text {th }}, 10^{\text {th }}, 11^{\text {th }}\right.$, and $12^{\text {th }}$ grades $)$ mathematics curriculum and guide, Ankara: Ankara: MNE Publication, 2011.

[24] March, T. What WebQuests (really) are? [online], 2003a. (22 February 2017); http://tommarch.com/writings/what-WebQuests-are/
[25] March, T. The learning power WebQuests. Educational Leadership, 42-47. 2003b (13 March 2017); http://tommarch.com/writings/ascdWebQuests/

[26] Yang, K. H. The WebQuest model effects on mathematics curriculum learning in elementary school students. Computers \& Education, 72, 158-166, 2014.

[27] Wooster, D. \& Lemcool, K. WebQuests: An instructional strategy for the occupational therapy classroom. Occupational Therapy In Health Care, 18, 1, 2004.

[28] Yıldırım, A. \&Șimșek, H. Sosyal Bilimlerde Nitel Araștırma Yöntemleri [Qualitative Research Methods in Social Sciences] (6th edition). Ankara: Seçkin Yayıncılık, 2006.

[29] Türnüklü, A. Eğitimbilim araştırmalarında etkin olarak kullanılabilecek nitel bir araştırma tekniği: Görüşme [A qualitative research technique to be efficiently used in pedagogical researchers: Interview]. Kuram ve Uygulamada Eğitim Yönetimi Dergisi, 24, 543-559, 2000.

[30] Tavșancıl, E. \& Aslan, E. Sözel, yazılı ve diğer materyaller için içerik analizi ve uygulama örnekleri [Content analysis and practical examples for oral, written and other materials]. İstanbul: Epsilon Yayınevi, 2001.

[31] Chuo, T.W.I. The Effect of The WebQuest Writing İnstruction On Efl Learners' Writing Performance, Writing Apprehension and Perception. Unpubleshed Doctoral Dissertation. University of Sierra, 2004.

[32] Smith, J. \& Robinson, S. Preparing future teachers to use technology, Remedial and Special Education, p. 24, Year 3, pp. 154-160, 2003.

[33] Zencirci, İ. \& Asker, E. A $\breve{g}$ araştırması (WebQuest) tasarlayıcılarının bu etkinliklerin hazırlanması sürecine ve Türkiye'de uygulanabilirliklerine ilişkin görüşleri [WebQuest designers' opinions on the preparation process of these activities and their applicability in Turkey]. Necatibey Eğitim Fakültesi Elektronik Fen ve Matematik Eğitimi Dergisi (EFMED), 3 (2), 124-148, 2009.

[34] Kurtuluş, A., Yanık, H. B. \&Ada, T. Middle school mathematics teachers' initial perception about WebQuests. International Commission for the Study and Improvement of Mathematics Education-CIEAEM 63, Barcelona, Spain, 2011.

[35] Manning, J. B. \& Carpenter, L. B. Assistive technology WebQuest: improving learning for preservice teachers. TechTrends, 52 (6), 47-52, 2008.

[36] Yücel, Z. WebQuest destekli matematik öğretiminin altıncı sınıf öğrencilerinin eleștirel düşünme becerilerine etkisi [How WebQuest-aided mathematics instruction affects sixth-grade students' critical thinking skills]. Postgraduate Thesis, Süleyman Demirel University, Institute of Science, Isparta, 2011.

[37] Halat, E. \& Jakubowski, E. Teaching Geometry Using WebQuest. 19th International Conference on Technology and Education. Tallahasse, Florida, 2011.

[38] Jones R. G. Emerging Technologies, Language in Action: From WebQuests to Virtual Realities, Language Learning \& Technology, Vol.: 8, Issue: 3, p. 9-14, 2004.

[39] Stipek, D. Motivation to learn from theory to practice, Needham Heights, MA: Allyn and Bacon a Viacom Company, 1998. 
[40] Köse, F. Moving the WebQuest process from static to dynamic: preservice teachers' experience with the dynamic WebQuest environment. Master Thesis. Middle East Technical University, Ankara, 2007.

[41] Chang, C., Chen, T. \& Hsu, W., The study on integrating WebQuest with mobile learning for environmental education. Computers \& Education, 57, 1228-1239, 2010.

i An earlier version was presented at " $\sigma^{\text {th }}$ Cyprus International Conference on Educational Research (CYICER-2017)" a conference held at North Cyprus, May 2017.
[42] Gaskill, M., McNulty, A. \& Brooks, D. W. Learning from WebQuests. Journal of Language Teaching and Research, 15(2), 133-136, 2006.

[43] Cruz, S. C., \& Carvalho, A. A. A WebQuest about tuthankamen. Computers and Education, 21(3), 207-217, 2008 .

[44] Dodge, B. WebQuests: A technique for internet-based learning. Distance Educator, 1(2), 10-13, 1995.

[45] Sandars, J. Using WebQuests to enchance work based learning. Work Based Learning in Primary Care, 3(3), 210-217, 2005 